\title{
Analysis of the seroprevalence of and factors associated with Chagas disease in an endemic area in northeastern Brazil
}

\author{
Erlane Chaves Freitas ${ }^{[1]}$, Maria de Fátima Oliveira ${ }^{[2]}$, Arduina Sofia Ortet de Barros Vasconcelos ${ }^{[2]}$, \\ José Damião da Silva Filho ${ }^{[1]}$, Carlos Eduardo Menezes Viana ${ }^{[1]}$, \\ Kátia Cristina Morais Soares Gomes ${ }^{[3]}$ and Luciano Pamplona de Góes Cavalcanti ${ }^{[1],[4]}$
}

[1]. Programa de Pós-Graduação em Patologia, Departamento de Patologia e Medicina Legal, Universidade Federal do Ceará, Fortaleza, Ceará, Brasil.

[2]. Departamento de Análises Clínicas e Toxicológicas, Faculdade de Farmácia, Universidade Federal do Ceará, Fortaleza, Ceará, Brasil.

[3]. Departamento de Química, Faculdade de Ciências e Bioquímica, Universidade de Lisboa, Lisboa, Portugal.

[4]. Departamento de Saúde Comunitária, Faculdade de Medicina, Universidade Federal do Ceará, Fortaleza, Ceará, Brasil.

\begin{abstract}
Introduction: Chagas disease (CD) is currently considered a neglected disease; hence, identifying the factors associated with its high prevalence is essential. This study aimed to identify the seroprevalence of and the possible factors associated with CD in inhabitants of the City of Limoeiro do Norte, northeastern Brazil. Methods: Between April and November 2013, blood collection was conducted and a semi-structured questionnaire was administered. Blood samples that showed positive or possible serology for anti-Trypanosoma cruzi antibodies based on indirect immunofluorescence, hemagglutination indirect, and an enzyme-linked immunosorbent assay were analyzed. Associations between CD positivity and the study variables were analyzed using prevalence ratios (PR) with 95\% confidence intervals (CI). Results: A total of 812 individuals were analyzed, of which T. cruzi seropositivity was determined in $4.2 \%$ (34 individuals). Sociodemographic variables showing a significant association with $T$. cruzi positivity included age $>50$ years $(\mathrm{PR}=27.6 ; 95 \% \mathrm{CI}=6.66-114.4)$, elementary level education $(\mathrm{PR}=5.15 ; 95 \%$ $\mathrm{CI}=1.83-14.47)$, and retirement $(\mathrm{PR}=7.25 ; 95 \% \mathrm{CI}=3.72-14.14)$. Positivity for $T$. cruzi was 6.17 times higher in those who had a history of living in rammed earth houses compared with those who did not $(95 \% \mathrm{CI}=2.19-17.37)$. There was no evidence of vertical transmission in the individuals studied. Among the individuals infected with T. cruzi, the majority reported having a comorbidity $(\mathrm{p}<0.01)$. Conclusions: This study demonstrated the seroprevalence of CD and identified factors associated with a high prevalence of CD.
\end{abstract}

Keywords: Chagas disease. Seroepidemiological investigation. Trypanosoma cruzi. cross-sectional study.

\section{INTRODUCTION}

Chagas disease $(\mathrm{CD})$ remains an important health problem in Latin America and is recognized by the World Health Organization as one of the 13 neglected tropical diseases ${ }^{1}$. There are 7-8 million infected people worldwide, with 75-90 million people at potential risk of infection and $>10,000$ deaths $/ \mathrm{year}^{2,3,4}$. In Brazil, 2-3 million people are infected with Trypanosoma cruzi, which generates a high social and financial cost, as well as the need for continuous surveillance ${ }^{5,6}$.

Historically, the results of at least two National Serological Investigations, which were performed from 1975-1980 and 2001-2008, have been published in the literature ${ }^{7,8,9}$.

Corresponding author: Dr. Luciano Pamplona de Góes Cavalcanti. e-mail: pamplona.luciano@gmail.com

Received 24 June 2016

Accepted 24 October 2016
In 1921, the presence of infected triatomine bugs was first described for the cities of Cariri and Quixadá ${ }^{10}$. However, the first cases of CD (also in Cariri) were not diagnosed until $1942^{11,12}$. Since the time of identification of these early cases until the official institution of the Campaign for Chagas Disease Control (CCDCh) in 1975, several studies were performed and suggested the requirement for the initially affected cities to implement regular control activities ${ }^{13}$.

A serological study conducted in 1967 in the State of Ceará showed a prevalence of CD infection of $14.8 \%{ }^{13}$. More recently, $16.7 \%$ of samples from the City of Limoeiro do Norte, which were analyzed using the complement fixation reaction, were seropositive for $\mathrm{CD}^{13}$. Seroepidemiological investigations conducted in Ceará in the 2000s showed that the CD prevalence in isolated cities ranged from $3.1 \%$ in Jaguaruana to $5.8 \%$ in Acopiara. Furthermore, triatomines were determined to be positive for the parasite T. cruzi in Limoeiro do Norte, at the same time ${ }^{14,15,16,17,18}$. 
In 2006, an outbreak of acute CD involving eight people in the City of Redenção and probable oral transmission was reported ${ }^{19}$. In the following decade, the prevalence decreased significantly across the state, reaching $0.02 \%$ according to an investigation of children from 2001-2008 . With a reduction in the prevalence of cases, the natural infection of triatomine, and the gradual decrease in the actions of the Control Program, the City of Limoeiro do Norte showed the highest rate of infection of captured triatomines (5\%) among the cities served by the Control Program of Chagas Disease of the Regional Laboratory of Endemics of Limoeiro do Norte, Ceará from 2009-2011 ${ }^{18}$. In a 2011 pilot study in Sapé, a region of the city, the prevalence of $\mathrm{CD}$ in humans was shown to be $2.6 \%{ }^{20}$.

Currently, there is the possibility of a gradual reduction in the entomological surveillance activities performed by the $\mathrm{CCDCh}$ due to the reallocation of agents to the dengue control program and before the initiation of active transmission of $\mathrm{CD}$, as anticipated in recent reports. This study aimed to identify the seroprevalence of $\mathrm{CD}$ and the factors associated with $\mathrm{CD}$ prevalence in the City of Limoeiro do Norte, Northeastern Brazil.

\section{METHODS}

\section{Ethical considerations}

Following Resolution no. 466 of December 12, 2012, the research was submitted and approved by the Research Ethics Committee of the Federal University of Ceará (approval number: 237,128; CAAE: 13298513.5.0000.5054).

\section{Design and study area}

A cross-sectional study and seroepidemiological investigation was conducted in the City of Limoeiro do Norte, northeastern Brazil. To calculate the sample size, the CD prevalence was estimated to be $5 \%$, considering an error of $\pm 3.5 \%$ with a $95 \%$ confidence interval (CI). Following these parameters, and adding a possible loss of $10 \%$, a minimum sample size of 799 people was estimated using StatCalc software 3.5.1.

Samples were collected from participants in health centers to ensure the health and safety of the patients. The seven health units with the largest number of enrollments were considered for inclusion in the study (Antônio Holanda de Oliveira, Luís Alves de Freitas, Santa Luzia, João XXIII, Cabeça Preta, Arraial, and Center).

\section{Material collection}

During visits by healthcare agents, individuals were informed about the study and were invited to participate. At the health centers, participants received information about the research and signed informed consent forms. For each participant, we collected $4.5 \mathrm{~mL}$ of blood and administered a semi-structured questionnaire, which was applied between April and November 2013. The semi-structured questionnaire comprised 32 questions related to the sociodemographic characteristics of individuals, general data, and risk factors for CD such as age, sex, schooling, place of birth, place of origin, knowledge about the transmitter bug (triatomine), possession of animals, types and characteristics of housing, a history of blood transfusion or donation, and a family history of CD. Additionally, we investigated other data (e.g., doctor's appointments) related to the use of healthcare services and comorbidities reported by the participants.

\section{Criteria for inclusion and exclusion}

Individuals of both sexes ( $>2$ years-of-age) who resided in the study area, signed the consent form, and permitted blood collection were included in the study. In the case of minors, their guardians signed consent forms and literate children signed assent forms. Individual were excluded if insufficient blood samples to perform the necessary examinations were obtained.

\section{Biological sample}

Blood samples were collected via venipuncture without anticoagulant in tubes containing separation gel. Blood samples were centrifuged at 2,500 rotations/minute for 8 minutes. After centrifugation, the supernatant (serum) was aspirated into a prelabeled 2-mL microtube, packed in a cooler with ice, and transported to the Laboratory for Research on Chagas Disease (LPDC) of the Department of Clinical and Toxicological Analysis of the Federal University of Ceará. The samples were stored in a freezer at $-20^{\circ} \mathrm{C}$ until serological testing was completed.

\section{Serological tests}

For the serological analysis conducted at the LPDC, enzymelinked immunosorbent assays (ELISAs) were performed. Briefly, the tests were conducted at a dilution of $1: 25$, according to the recommendation of the Wama diagnóstica ${ }^{\circledR}$ kit of ELISA for CD. Sera showing positivity or possible serology for anti-T. cruzi antibodies were forwarded to the Central Public Health Laboratory of Ceará, where they were analyzed using three different methods: indirect immunofluorescence (IIF), hemagglutination inhibition (HAI), and ELISA. Positive results in at least two of the three serological testing methods were considered positive ${ }^{21}$.

Non-reactive sera were released as negative, based on Ordinance 2,712/2013, which redefines the technical regulation of hemotherapy procedures and allows blood units that are nonreactive for anti-T. cruzi antibodies in a high-sensitivity test, such as an ELISA, to be released.

Participants with seronegative results received the results of the laboratory tests in their residences during scheduled visits by healthcare agents. Individuals with positive results received their test results with proper information on the disease and were forwarded to a physician for evaluation (clinical, laboratorial, and epidemiological) at the Walter Cantídio University Hospital.

\section{Statistical analysis}

The analyses were performed using GraphPad Prism 5 and the Epi info software, version 3.5.4. Associations between $T$. cruzi positivity and the study variables were determined using Fisher's chi-squared or exact test and are shown as prevalence ratios (PR) with $95 \%$ CIs. $\mathrm{P}<0.05$ was considered statistically significant. 


\section{RESULTS}

\section{Characterization of the study population}

Blood samples were collected from 812 individuals at seven healthcare units (Table 1). The average age of the patients was 40.8 years, ranging from 2 to 86 years. Additional characteristics of the participants were as follows: $557(68.6 \%)$ were female, $383(47.2 \%)$ were aged $<39$ years, $759(94.4 \%)$ had a family income of $<2$ times the minimum wage, $481(59.3 \%)$ attended elementary school, and $527(64.9 \%)$ were from Limoeiro do Norte. Among the registered occupations, agriculture was the most cited [203 (25\%) individuals]. We interviewed 493 women ( $>15$ years of age), of which 144 (29.2\%) reported having had at least one abortion.

Regarding family history of CD, 243 (30\%) respondents had a relative with a $\mathrm{CD}$ diagnosis. Among these participants, 27 $(11.5 \%)$ responded that the mother had the disease. In relation to their previous residences, $402(54 \%)$ participants resided in rammed earth houses. Regarding blood transfusions, 123 $(15.1 \%)$ reported having made at least one donation and 59 $(7.3 \%)$ claimed to have received blood at least once in their lives.

Most respondents reported the presence of insects and/ or rodents in their residences [641 (79.3\%) individuals] and were able to accurately identify the triatomine [547 (67.7\%) individuals].

\section{Serological analysis of anti-Trypanosoma cruzi antibodies}

The results of the serological tests showed that 33 individuals were seropositive for $\mathrm{CD}$ and one was of an indeterminate serology. The participant with indeterminate results was considered positive in this study, as she had a current positive IIF test result, as well as positive results from prior ELISA and IIF testing of a blood sample from a reference laboratory in 2012. Furthermore, she reported during a subsequent interview that she had already received etiological treatment. Therefore, the prevalence of CD was of $4.2 \%(34 / 812)$ in the studied area (Table 2).

In the study population, seropositive individuals were detected in all health units. Four (11.8\%) infected individuals reported having made a previous blood donation, although no additional information was obtained in order to elucidate the destination of these donations, and whether or not they were rejected.

\section{Analysis of factors associated with Chagas Disease}

Most confirmed cases were female $(73.5 \%)$, with an average age of 59.5 years (age range, $45-78$ years). There was a significant difference associated with an age of $\geq 50$ years compared with an age of $<50$ years $(p<0.01)$, while there was no significant difference between the sexes $(\mathrm{p}=0.53)$ (Table 3$)$.

Positivity for $\mathrm{CD}$ was 5.15 times higher among individuals who had a partial elementary school level education compared with those who had completed elementary school $(95 \% \mathrm{CI}=1.83-14.47$; $\mathrm{p}$ $<0.01)$. Despite the prevalence of infection being higher among individuals from Limoeiro do Norte compared with individuals from other cities of Ceará and other states, this difference was not significant $(\mathrm{PR}=1.13 ; 95 \% \mathrm{CI}=0.56-2.29 ; \mathrm{p}=0.73)$.
TABLE 1

Number of participants according to health unit.

\begin{tabular}{lcc}
\hline & \multicolumn{2}{c}{ Participants } \\
\cline { 2 - 3 } Health unit & number & percentage \\
\hline Santa Luzia & 65 & 8.0 \\
Antônio Holanda de Oliveira & 67 & 8.2 \\
João XXIII & 116 & 14.3 \\
Cabeça Preta & 124 & 15.3 \\
Luís Alves de Freitas & 135 & 16.6 \\
Center & 151 & 18.6 \\
Arraial & 154 & 19.0 \\
\hline Total & 812 & 100.0 \\
\hline
\end{tabular}

Conversely, the prevalence of positive serology among retirees was 7.2 times higher compared with other professions, which was significant $(95 \% \mathrm{CI}=3.72-14.14 ; \mathrm{p}<0.01)$ (Table 3).

We analyzed the results of the findings from 493 women ( $>15$ years-of-age); positivity for $\mathrm{CD}$ was 2.63 times higher for women who had undergone an abortion compared with those who had not $(95 \% \mathrm{CI}=1.23-5.62 ; \mathrm{p}=0.01)$.

The prevalence of seropositivity among individuals who had resided in rammed-earth houses in the past was 6.17 times higher compared with those who had never lived in this type of housing (95\% CI $=2.19-17.37$; $<<0.01$; Table 4). No significant difference in infection was observed with regard to the current housing conditions of the participants. Moreover, no association was found with respect to the type of house ( $\mathrm{p}=$ $0.58)$, having electric power $(\mathrm{p}=0.08)$, having running water ( $\mathrm{p}$ $=0.52)$, or the number of bathrooms in the residences $(\mathrm{p}=0.21)$.

Knowledge of the triatomine was not significantly associated with $\mathrm{CD}$, although it is important to note that the study participants who were aged $>30$ years were $83 \%$ more likely to identify the triatomine, as compared with those aged $<30$ years $(95 \% \mathrm{CI}=1.58-2.12 ; \mathrm{p}<0.01)$.

In this study, positivity for $\mathrm{CD}$ was 4.61 times higher among those who visited a physician $>2$ times/year $(95 \% \mathrm{CI}=1.79$ $11.87 ; \mathrm{p}<0.01) ; 2.16$ times higher among those who underwent testing with some frequency $(95 \% \mathrm{CI}=1.08-4.33 ; \mathrm{p}=0.03)$; 4.7 times higher among those who had a comorbidity $(95 \% \mathrm{CI}$ $=2.07-10.67 ; \mathrm{p}<0.01)$; and 3.92 times higher among those who reported having hypertension $(95 \% \mathrm{CI}=2.04-7.53$; $\mathrm{p}<$ 0.01) (Table 5).

\section{DISCUSSION}

In this study, the prevalence of CD in Limoeiro do Norte was $4.2 \%$, which was higher than the latest indexes reported for Northeastern Brazil. A fact that contributes to this finding is the higher sensitivity of the diagnostic tests used in this study compared with those used previously, such as in the national investigation of $1975-1980^{7,22}$. 
TABLE 2

Sociodemographic and epidemiological aspects of positive cases for Chagas disease in Limoeiro do Norte, Ceará, Brazil.

\begin{tabular}{|c|c|c|c|c|c|c|c|c|c|c|}
\hline Id & \multicolumn{3}{|c|}{ Serological confirmation } & \multicolumn{4}{|c|}{ Sociodemographic data } & \multicolumn{3}{|c|}{ Epidemiological aspects } \\
\hline 1 & $\mathrm{RS}$ & RS & NRS & $\mathrm{F}$ & 57 & CHS & Up to $2 \mathrm{MW}$ & No & NI & Yes \\
\hline 2 & $\mathrm{RS}$ & RS & $\mathrm{RS}$ & $\mathrm{F}$ & 78 & I & Up to $2 \mathrm{MW}$ & No & Yes & Yes \\
\hline 3 & $\mathrm{RS}$ & RS & $\mathrm{RS}$ & $\mathrm{F}$ & 58 & IES & Up to $2 \mathrm{MW}$ & No & Yes & No \\
\hline 6 & RS & RS & $\mathrm{RS}$ & $\mathrm{F}$ & 54 & IES & Up to $2 \mathrm{MW}$ & Yes & Yes & Yes \\
\hline 7 & $\mathrm{RS}$ & RS & $\mathrm{RS}$ & M & 53 & IES & Up to $2 \mathrm{MW}$ & Yes & Yes & Yes \\
\hline 8 & RS & RS & --- & $\mathrm{F}$ & 55 & IES & Up to $2 \mathrm{MW}$ & No & Yes & Yes \\
\hline 12 & RS & --- & RS & $\mathrm{F}$ & 66 & I & Up to $2 \mathrm{MW}$ & No & Yes & Yes \\
\hline 13 & RS & RS & RS & M & 68 & IES & Up to $2 \mathrm{MW}$ & Yes & No & Yes \\
\hline 14 & RS & RS & --- & $\mathrm{F}$ & 66 & IES & Up to $2 \mathrm{MW}$ & Yes & Yes & Yes \\
\hline 15 & $\mathrm{RS}$ & RS & --- & M & 54 & IES & Up to $2 \mathrm{MW}$ & No & Yes & Yes \\
\hline 16 & RS & RS & --- & M & 59 & IES & Up to $2 \mathrm{MW}$ & No & Yes & Yes \\
\hline 17 & $\mathrm{RS}$ & --- & $\mathrm{RS}$ & M & 58 & I & Up to $2 \mathrm{MW}$ & No & Yes & Yes \\
\hline 18 & $\mathrm{RS}$ & RS & --- & M & 68 & I & $\mathrm{Up}$ to $2 \mathrm{MW}$ & Yes & Yes & Yes \\
\hline 19 & $\mathrm{RS}$ & RS & --- & $\mathrm{F}$ & 60 & I & Up to $2 \mathrm{MW}$ & Yes & Yes & Yes \\
\hline 25 & $\mathrm{RS}$ & --- & $\mathrm{RS}$ & $\mathrm{F}$ & 61 & IES & Up to $2 \mathrm{MW}$ & No & Yes & Yes \\
\hline 26 & RS & RS & RS & F & 68 & IES & Up to $2 \mathrm{MW}$ & No & Yes & No \\
\hline 27 & $\mathrm{RS}$ & $\mathrm{RS}$ & --- & F & 61 & IES & Up to $2 \mathrm{MW}$ & No & No & No \\
\hline 28 & $\mathrm{RS}$ & RS & --- & M & 53 & CES & Up to $2 \mathrm{MW}$ & No & Yes & Yes \\
\hline 29 & $\mathrm{RS}$ & $\mathrm{RS}$ & --- & $\mathrm{F}$ & 64 & IES & Up to $2 \mathrm{MW}$ & Yes & Yes & Yes \\
\hline 30 & $\mathrm{RS}$ & RS & --- & M & 60 & IES & Up to $2 \mathrm{MW}$ & No & Yes & No \\
\hline 31 & IND & IND & IND & F & 61 & CHS & Up to $2 \mathrm{MW}$ & Yes & Yes & Yes \\
\hline 32 & $\mathrm{RS}$ & $\mathrm{RS}$ & --- & $\mathrm{F}$ & 62 & IES & Up to $2 \mathrm{MW}$ & No & No & Yes \\
\hline 33 & $\mathrm{RS}$ & $\mathrm{RS}$ & --- & $\mathrm{F}$ & 61 & IES & Up to $2 \mathrm{MW}$ & No & Yes & Yes \\
\hline 34 & RS & RS & --- & F & 47 & IHS & Up to $2 \mathrm{MW}$ & No & Yes & Yes \\
\hline
\end{tabular}

Id: identification; ELISA: enzyme-linked immunosorbent assay; IIF: indirect immunofluorescence; HAI: hemagglutination inhibition assay; Fam hist CD: family history of Chagas disease; Resided REH: resided in rammed earth house; RS: reagent serum; NRS: non-reagent serum; CHS: complete high school; MW: minimum wage;- No: not; NI: non-informed; F: female; M: male; I: illiterate; IES: some elementary school; ---: test not performed; School - education level; Insect presence - reports the presence of insects; IND: indeterminate; CES: complete elementary school; IHS: incomplete high school. 
TABLE 3

Sociodemographic characteristics of participants.

\begin{tabular}{|c|c|c|c|c|c|c|c|}
\hline Variable & \multicolumn{2}{|c|}{ Positive } & \multicolumn{2}{|c|}{ Negative } & PR & P-value & $95 \%$ CI \\
\hline \multicolumn{8}{|l|}{$\overline{\text { Sex }}$} \\
\hline male & 9 & 3.5 & 246 & 96.5 & & & \\
\hline \multicolumn{8}{|l|}{ Age (years) } \\
\hline \multicolumn{8}{|l|}{ Income } \\
\hline$<1$ minimum wage & 1 & 0.9 & 104 & 99.1 & 0.20 & 0.11 & $0.03-1.46$ \\
\hline$\geq 1$ minimum wage & 33 & 4.7 & 45 & 95.3 & & & \\
\hline \multicolumn{8}{|l|}{ Schooling } \\
\hline until IES & 30 & 6.2 & 451 & 93.8 & 5.15 & $<0.01$ & $1.83-14.47$ \\
\hline other cities & 11 & 3.9 & 274 & 96.1 & & & \\
\hline \multicolumn{8}{|l|}{ Occupation } \\
\hline farmer & 7 & 3.4 & 197 & 96.6 & 0.74 & 0.46 & $0.33-1.67$ \\
\hline other & 27 & 4.6 & 554 & 95.4 & & & \\
\hline retired & 21 & 14.7 & 122 & 85.3 & 7.25 & $<0.01$ & $3.72-14.14$ \\
\hline other & 13 & 2.0 & 629 & 98.0 & & & \\
\hline housewife & 3 & 5.4 & 539 & 94.6 & 0.13 & $<0.01$ & $0.04-0.42$ \\
\hline other & 31 & 4.3 & 698 & 95.7 & & & \\
\hline
\end{tabular}

IES: some elementary school; CES: complete elementary school; PR: prevalence ratio; 95\% CI: 95\% confidence interval.

TABLE 4

Analysis of biological risk factors for CD in participants.

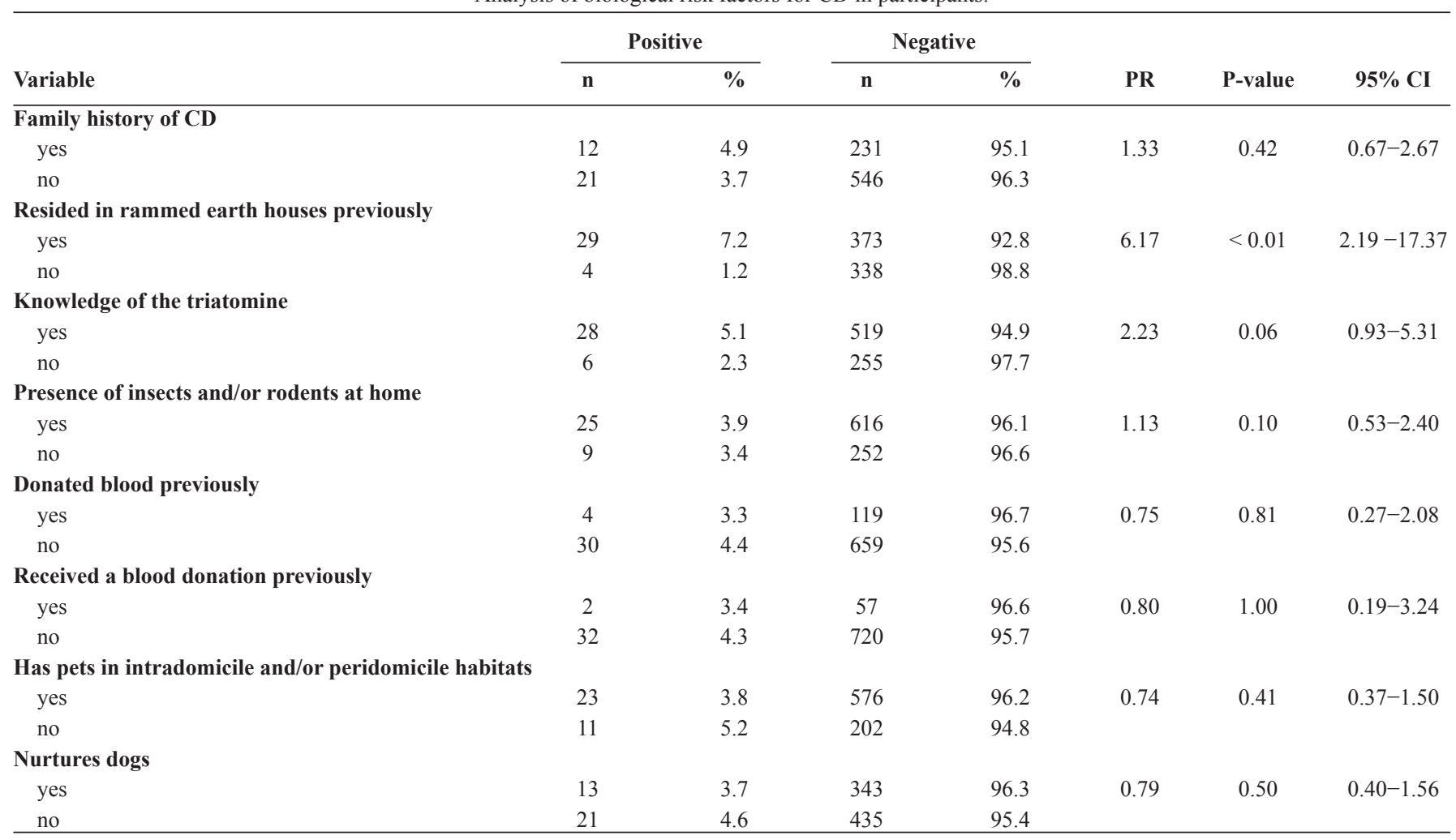

CD: Chagas disease; PR: prevalence ratio; $\mathbf{9 5 \%}$ CI: 95\% confidence interval. 
TABLE 5

Statistical analysis of the use of healthcare services and comorbidities in participants.

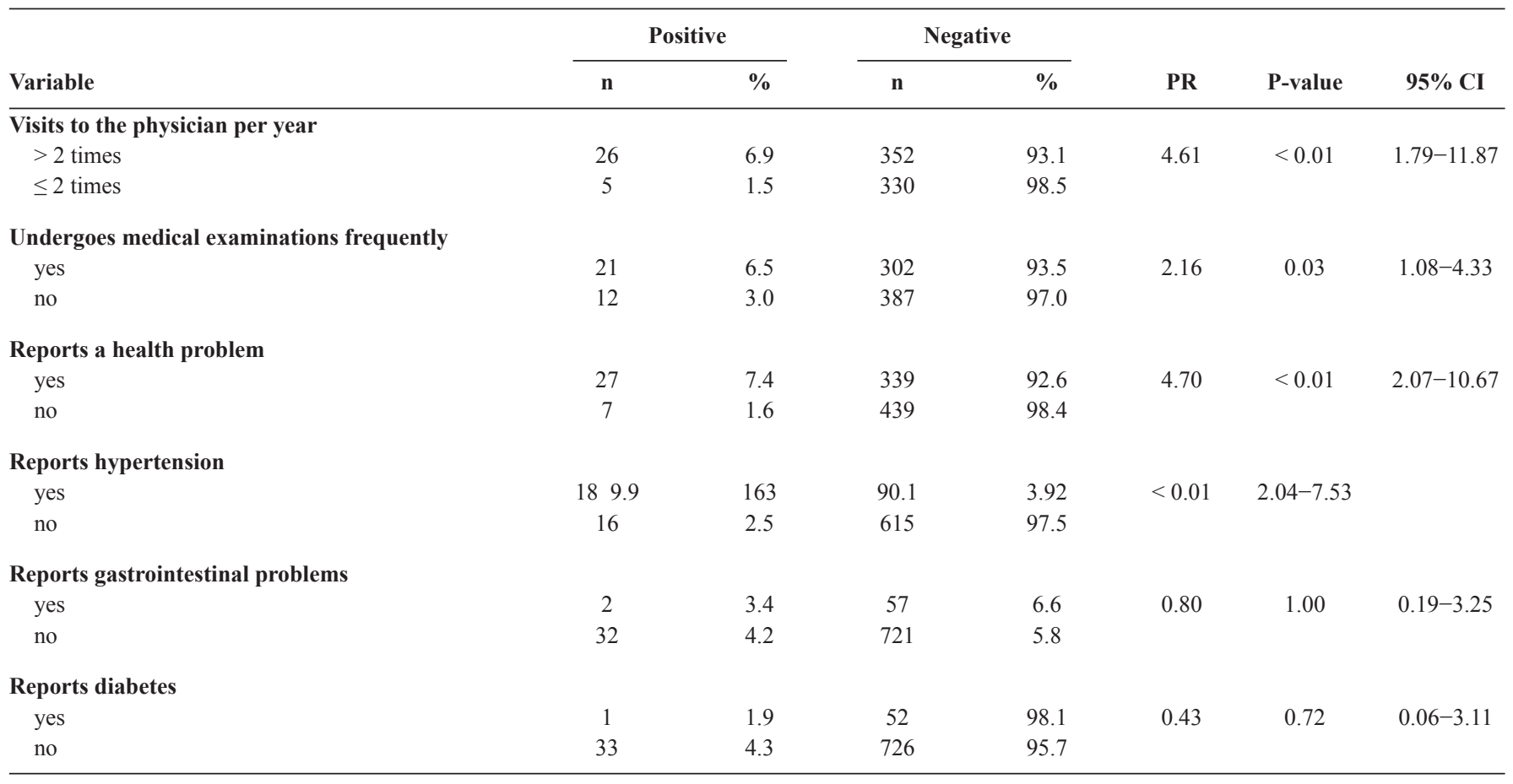

PR: prevalence ratio; 95\% CI: 95\% confidence interval.

Limoeiro do Norte has reported CD cases for many decades, with an estimated prevalence of $16.7 \%$ in the year of 1967 , as well as the presence of several species of triatomine (predominance of T. brasiliensis and T. pseudomacula) $)^{13,18,21}$. The decline in the prevalence of infection by T. cruzi in Limoeiro do Norte from $16.7 \%$ in 1959 to $4.6 \%$ in $1970-1977$ and to $4.2 \%$ in 2013 can be explained, among other factors, by vector control measures and greater awareness among the local population ${ }^{13}$. Even with this significant reduction, the high $(4.2 \%) \mathrm{CD}$ prevalence in this study compared with other Brazilian studies can be explained by the higher sensitivity and specificity of recently used methods ${ }^{14,23,24,25,26}$.

In this study, the infection rate was higher (27 times) in the population aged $\geq 50$ years. This result is consistent with those found in other regions, suggesting that $\mathrm{CD}$ is residual with these individuals who likely acquired the disease decades previously. Presently, more effective control of vector-borne transmission

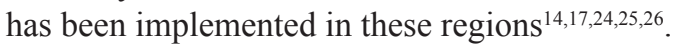

CD positivity was 5 times higher among those who had only partially attended elementary school compared with those who completed elementary school. This result was also observed in previous studies, regardless of the region of the country ${ }^{23,27,28,29}$, indicating that a higher education level is associated with a lower CD prevalence.

The CD prevalence was 2.63 times higher in the group of women aged $>15$ years who had a history of abortion compared with those who did not. Care must be taken in interpreting these data, since we did not ask whether the abortion was spontaneous or induced and, although CD can lead to abortion, the etiology can be multifactorial ${ }^{30}$. However, it is important to include this variable in future prospective studies.

An important association was observed between those who had a history of residing in a rammed-earth house and positivity for $\mathrm{CD}$; the $\mathrm{CD}$ prevalence was 6.17 times higher in those who had lived in rammed-earth housing compared with those who had not. This higher seroprevalence was not affected by currently dwelling in a house of masonry, but was related to having previously lived in rammed-earth houses. It is likely that the residents of these houses had been infected in previous homes with conditions suited for vector transmission. There is strong evidence suggesting that masonry houses offer greater protection against vector-borne transmission ${ }^{31,32}$.

In this study, older participants reported better knowledge of triatomines than younger participants, and this knowledge was significantly related to age. This same finding was verified in the City of Botucatu, State of São Paulo in the past decade ${ }^{29}$. This finding was expected, as the current generation typically considers $\mathrm{CD}$ as a major public health problem of the past as a result of the government programs for vector control.

The high prevalence of hypertension among infected patients is likely not associated with $\mathrm{CD}$, although hypertension was the most common cardiovascular disease among the chagasic population in other regions ${ }^{16,33,34,35}$. There is a consensus that $\mathrm{CD}$ and its association with other chronic diseases can increase morbidity and mortality and worsen the quality of life of those with hypertension ${ }^{34}$. This fact should cause concern and reorient 
the prevention and monitoring activities for those aged $>50$ years of age ${ }^{36}$. Information about comorbidities were collected via interviews, which is an important limitation of this study. Issues related to providing information to a population with a limited education and the lack of clinical and laboratory exams to confirm the reported comorbidities were also limitations of this study.

The magnitude and dispersal of vector-borne diseases, including dengue fever and, more recently, Zika virus, which result in the allocation of the majority of investments to vectorborne disease control programs, further weakens the few remaining triatomine control programs. Efforts to educate local populations in the identification of triatomines and to notify health authorities must be expanded and strengthened in order to maintain previous achievements in controlling this disease. Currently, in most regions of Brazil, chronic cases of CD caused by infections acquired in the past prevail, with an increase in the occurrence of acute $\mathrm{CD}$ observed in the states of the Legal Amazon. Changing this epidemiological framework of $\mathrm{CD}$ in Brazil should promote important discussions about future actions and strategies concerning the surveillance, prevention, and control of vectors.

\section{Acknowledgments}

We would like to thank staff at the Central Public Health Laboratory of Ceará for providing technical support for the development and implementation of this study.

\section{Conflict of interest}

The authors declare that there is no conflict of interest.

\section{REFERENCES}

1. World Health Organization (WHO). Chagas disease: Fact sheet. Geneve: Technical Report Series 2013; 304:1-4.

2. Coura JR, Dias JCP. Epidemiology, control and surveillance of Chagas disease - 100 years after its discovery. Mem Inst Oswaldo Cruz. 2009; 104 (supl I):31-40.

3. Rassi Jr A, Rassi A, Marin-Neto JA. Chagas disease. Lancet. 2010; 375:1388-402.

4. Centers for Disease Control and Prevention (CDC). Parasites - American Trypanosomiasis (also known as Chagas Disease): Epidemiology \& Risk Factors. Atlanta: GA, USA. Accessed 2013 November. Available at: http://www.cdc.gov/parasites/chagas/epi.html.

5. Dias JCP. Globalização, iniquidade e doença de Chagas. Cad Saude Publica. 2007; 23(supl 1):S13-S22.

6. Oliveira MF, Nagao-Dias AT, Pontes VMO, Souza Jr AS, Coelho HLL, Coelho ICB. Tratamento etiológico da doença de Chagas no Brasil. Rev Pat Trop. 2008;37(3):209-28.

7. Camargo ME, Silva GR, Castilho EA, Silveira AC. Inquérito sorológico da prevalência da infecção chagásica no Brasil, 19751980. Rev Inst Med Trop São Paulo. 1984;26(4):192-204.

8. Portela-Lindoso AAB, Shikanay-Yasuda MA. Doença de Chagas crônica: do xenodiagnóstico e hemocultura à reação em cadeia da polimerase. Rev Saúde Pública. 2003;37(1):107-15.

9. Ostermayer AL, Passos ADC, Silveira AC, Ferreira AW, Macedo V, Prata AR. O inquérito nacional de soroprevalência de avaliação do controle da doença de Chagas no Brasil (2001-2008). Rev Soc Bras Med Trop. 2011; 44(supl 2):108-21.
10. Alencar JE, Santos AR, Bezerra OF, Saraiva TM. Distribuição geográfica dos principais vetores de endemias no Estado do Ceará. - I - Triatomíneos. Rev Soc Bras Med Trop. 1976; 10(5):261-84.

11. Alencar JE. Estudos sobre a epidemiologia da doença de Chagas no Ceará. III Região do Baixo Jaguaribe. Rev Bras Malariol D Trop. 1965;17:149-56.

12. Machado H, Pinto OF. Contribuição ao conhecimento da distribuição geográfica dos triatomíneos domiciliários e de seus índices de infecção natural no Estado do Ceará, Brasil. Rev Bras Malariol D Trop. 1952; 4:157-70.

13. Alencar JE. História Natural da Doença de Chagas no Estado do Ceará. Imprensa Universidade da Universidade Federal do Ceará, Fortaleza: 1987. 341p.

14. Diotaiuti L, Faria-Filho OF, Carneiro FC, Dias JC, Pires HH, Schofield CJ. Aspectos operacionais do controle de Triatoma brasiliensis. Cad Saude Publica. 2000;16(supl 2):61-7.

15. Freitas SPC, Freitas ALC, Gonçalves TCM. Ocorrência de Panstrongylus lutzi no peridomicílio, Estado do Ceará, Brasil. Rev Saude Pública. 2004;38(4):579-80.

16. Pereira CM. Estudo soroepidemiológico de anticorpos antiTrypanosoma cruzi no município de Acopiara - CE. Monografia (Graduação em Farmácia) - Faculdade de Farmácia da Universidade Federal do Ceará, Fortaleza: 2006. 95 p.

17. Borges-Pereira J, Sarquis O, Zauza PL, Britto C, Lima MM. Epidemiologia da doença de Chagas em quatro localidades rurais de Jaguaruana, Estado do Ceará. Soroprevalência da infecção, parasitemia e aspectos clínicos. Rev Soc Bras Med Trop. 2008;41(4):345-351.

18. Vasconcelos ASOB, Freitas EC, Andrade MC, Lima MM, Pereira LS, Gomes KCMS, et al. Doença de Chagas: situação vetorial no município de Limoeiro do Norte - CE, no período de 2006 a 2009. Rev Inst Adolfo Lutz. 2013;72(4):295-301.

19. Cavalcanti LPG, Rolim DB, Pires Neto RJ, Vilar DCLF, Nogueira JOL, Pompeu MML, et al. Microepidemia de doença de Chagas aguda por transmissão oral no Ceará. Cad Saude Colet. 2009;17(4):911-21.

20. Freitas EC, Oliveira MF, Andrade MC, Vasconcelos ASOB, SilvaFilho JD, Candido DS, et al. Prevalence of Chagas disease in a Rural area in the State of Ceara, Brazil. Rev Inst Med Trop São Paulo. 2015;57(5):431-33.

21. Ministério da Saúde. Secretaria de Vigilância em Saúde. Consenso Brasileiro em Doença de Chagas. Rev Soc Bras Med Trop. 2005;38 (supl III):1-29.

22. Dias JCP, Machado EMM, Fernandes AL, Vinhaes MC. Esboço geral e perspectivas da doença de Chagas no Nordeste do Brasil. Cad Saude Publica. 2000;16(Supl 2):13-34.

23. Borges-Pereira J, Castro JAF, Silva AR, Zauza PL, Bulhões TP, Goncalves ME, et al. Soroprevalência da infecção chagásica no Estado do Piauí, 2002. Rev Soc Bras Med Trop. 2006(6):39: 530-39.

24. Coutinho CFS. Fatores associados ao risco para doença de Chagas em área rural do Município de Russas - Ceará, Brasil: abordagem espacial. Dissertação de Mestrado. Rio de Janeiro: Escola Nacional de Saúde Pública Sérgio Arouca; 2010. 75p.

25. Silva EM, Rocha MOC, Silva RC, Paixão GC, Buzzati H, Santos NA, et al. Estudo clínico-epidemiológico da doença de Chagas no distrito de Serra Azul, Mateus Leme, centro-oeste do Estado de Minas Gerais. Rev Soc Bras Med Trop. 2010;43(2):178-81.

26. Brito CRN, Sampaio GHF, Camara ACJ, Nunes DF, Azevedo PRM, Chiari E, et al. Seroepidemiology of Trypanosoma cruzi infection in the semiarid rural zone of the State of Rio Grande do Norte, Brazil. Rev Soc Bras Med Trop. 2012;45(3):346-52. 
27. Pompilio MA, Dorval MEMC, Cunha RV, Britto C, Borges-Pereira J. Aspectos epidemiológicos, clínicos e parasitológicos da doença de Chagas em Mato Grosso do Sul. Rev Soc Bras Med Trop. 2005; 38(6):473-78

28. Costa WP, Da Cruz-Costa AMS, Vieira IAC, Passos ATB, Batista JS. Perfil sócio-cultural-econômico dos portadores de doença de Chagas em áreas endêmicas na zona rural do município de Mossoró-RN. Rev Verde. 2007;2(2):101-6.

29. Godoy I, Meira DA. Soroprevalência da infecção chagásica em moradores de municípios da região de Botucatu, Estado de São Paulo. Rev Soc Bras Med Trop. 2007;40(5):516-20.

30. Barbaresco AA. Análise dos resultados sorológico, anatomopatológico e parasitológico de material abortivo para infecções com risco de transmissão vertical com ênfase na toxoplasmose. Dissertação de Mestrado. Goiânia: Instituto de Patologia Tropical e Saúde Pública da Universidade Federal de Goiás; 2009. 100p.
31. Pessôa SB, Martins AV. Parasitologia médica $11^{\mathrm{a}}$ edition, Rio de Janeiro: Guanabara Koogan, 1982.

32. Dias JCP. Perspectivas e controle da doença de Chagas no Brasil. Cad Saude Publica. 1986;2(1):84-103.

33. Oliveira FAZ, Bicalho GVC, Souza-Filho LD, Silva MJ, Gomes Filho ZC. Características epidemiológicas dos pacientes com doença de Chagas. Rev Bras Med Fam Com. 2006;2(6):107-13.

34. Almeida EA, Barbosa Neto RM, Guariento ME, Wanderley JS, Souza ML. Apresentação clínica da doença de Chagas crônica em indivíduos idosos. Rev Soc Bras Med Trop. 2007;40(3):311-15.

35. Guariento ME, Alliegro FC, Almeida EA. Doença de Chagas associada a doenças crônicas em pacientes assistidos em ambulatório de hospital universitário. Rev Bras Clin Med. 2009;7:84-8.

36. Guariento ME, Ramos MC, Gontijo JAR, Carvalhal SS. Doença de Chagas e hipertensão arterial primária. Arq Bras Cardiol. 1993;60:71-5. 